This chapter examines how college union professionals can keep up with changes in technology and address student expectations regarding information technology.

\title{
Impact and Evolution of Technology in College Unions
}

\author{
John Taylor, Rich Steele
}

Today's college students have grown up in a world immersed in technology, so much so that it has become an essential part of their daily life (Martinez Aleman \& Wartman, 2009). Their familiarity and use of technology is strong, with $86 \%$ having a computer prior to coming to college, $88 \%$ owning a cell phone, and $88 \%$ accessing the Internet daily (Student Monitor, 2013). Students enter college with an increased understanding of how to use technology tools and are considered to be one of the most Internetactive groups in the United States (Jones, 2002). Recognizing the increasing use of technology by students, it is important for professionals working in college unions to be as current as possible in the technology arena and to understand student expectations regarding information technology (IT).

College union facilities have provided a venue for the use of technology on campus with examples that date to the early twentieth century. At the Oxford Union, a telegram board was used by the campus community to share news and events and a photographic dark room was available for community use in Houston Hall at the University of Pennsylvania (Butts et al., 2012). Directors of the college union have consistently considered the role of technology within the physical building design, as evidenced by Porter Butts's 1938 description of the Wisconsin Union, "When we open the new rooms, we open also new frontiers ... in the special technique of radio drama, in the making as well as the showing of sound moving pictures" (Butts et al., 2012, p. 60). Over the years, the greatest challenge for professionals in college unions has been to stay current with technology and students' use of technology. For example, college campuses in the 1990s were barely able to fund Ethernet in college union facilities when technology and student standards advanced to a new wireless platform. College union professionals, however, continue to recognize the importance of using technology as a valuable tool in the delivery of programs, services, and cocurricular educational experiences. In 2005, the Association of College Unions 
International (ACUI, 2012) identified technology as one of the eleven core competencies for the profession. The use of technology in higher education has provided the opportunity for the creation of "communities for work, play, and learning in ways unimaginable [over] a decade ago" (Duderstadt, Atkins, \& Van Houweling, 2006, Preface). McElvain and Smyth (2006) emphasized that using technology as an educational tool enhances engagement and learning. This calls attention to the fact that professionals working in college unions need to adapt technology that encourages the college union's role as a campus community builder.

Overall, professionals in the field of student affairs are typically less familiar with the new methods of technology than students (Junco \& Cole-Avent, 2008), especially those associated with using social media as a form of communication (Junco \& Mastrodicasa, 2007; Martinez Aleman \& Wartman, 2011). Student affairs professionals have recognized for more than a decade that the students attending college expect a sophisticated level of technology to be used throughout their collegiate experience (Blimling, 2000). This is further validated by the recognition that technology is considered a core competency by student affairs professional associations (ACPA/NASPA, 2010; ACUI, 2012). Professionals working in college unions need to be aware of how technology can be a partner in increasing student engagement in relation to both the operation of college union facilities and programming initiatives, given that the intentional use of technology has been linked to an increase in student engagement (Astin, 1999; $\mathrm{Hu} \&$ Kuh, 2001; Nelson Laird \& Kuh, 2005). This chapter explores the impact of technology on college unions and offers practical solutions for using technology to enhance both the operational efficiency of the facility and student programming engagement.

\section{Facility Operations}

A college union's physical building can range from historic structures with an antiquated infrastructure to buildings recently constructed that house the most up-to-date technology. Whether updating an existing building or planning for a new facility, technology solutions are available to maximize guest satisfaction and Internet access, building efficiency and sustainability, and improve the campus community's safety within the facility. The technology solutions that are found within a college union's facility range from energy efficient infrastructures to web-based reservations systems that are available to simplify access for the entire campus community. The technology systems that enhance the environmental conditions (e.g., room temperature, lighting, etc.) are frequently not visible to the public, rather they are the aspects of college union operation that create a comfortable place to learn and socialize. Systems that support remote monitoring and control of heating, ventilation, and air conditioning (HVAC) can provide data that inform preventive maintenance plans and optimize building performance. 
The use of data from these types of information technology systems has changed the management and administrative processes within higher education throughout the institution (Duderstadt et al., 2006).

The recent emphasis to achieve Leadership in Energy and Environmental Design (LEED ${ }^{\circledR}$ ) certification with campus buildings has prompted attention on energy management and building automation. Institutions seeking LEED ${ }^{\circledR}$ certification for campus buildings want to demonstrate a conscious effort to minimize the impact of the buildings lifecycle on the environment (Lange $\&$ Kerr, 2013). The five environmental criteria that are associated with LEED ${ }^{\circledR}$ certification include: sustainable site; water efficiency; energy and atmosphere; materials and resources; and indoor environmental quality. Within college union facilities that are LEED ${ }^{\circledR}$ certified, technology tools that are used to support sustainable practice include occupancy and photo sensors that create automated illumination to reduce energy consumption when a room is not in use. Advances in lamp technology offer retrofit and new installation options for energy efficient lighting using compact fluorescent (CFL) and light-emitting diode (LED) lamps. Automated window shades control the effect of sunlight on ambient indoor conditions. Tools that monitor and display power consumption in real time also encourage behavioral change with end users and facility managers to reduce consumption. These intelligent building systems also require facility maintenance and operations staff who are able to operate more complex and computer-driven systems. This shift in personnel requirements for operational staff within college unions will also impact the focus of some of those positions to be more grounded in skills and knowledge associated with information technology.

More than ever, security is an important issue on college campuses, and college union professionals need to recognize that as a public facility, they must balance the expectation of providing an accessible and comfortable environment for the campus community with the need for increased security for those individuals using the building. Crime and violence on campus has become more prevalent and college campuses need to create an environment where there is perceived to be effective security (Chekwa, Thomas, $\&$ Jones, 2013). Monitoring the people who enter and leave a college union can be challenging. Two common tools available to monitor access include card access systems and security cameras. While many college unions have open doors during regular operating hours, a card access system allows for better security during off hours. Designated cardholders, such as student organization officers, can gain access to the building or an office through approval provided on their access card, often the campus ID. Similarly, security cameras can be strategically placed to monitor and record entrances or certain areas of a college union. Both security solutions are commonplace in public venues such as hotels, retail stores, and other campus facilities (e.g., residence halls and academic buildings). 
Technology systems within a college union also control the access and speed at which the campus community can access their personal technology tools within the facility. With students, faculty, and staff expecting wireless access during meetings and events, professionals in college unions need to be aware of how to meet the expanding demands for the individual use of technology. In 2012, the Georgia Tech Student Center upgraded network switches and wireless access points to accommodate student demand for faster and better wireless coverage. The speed of wireless access points is based on the current IEEE standard of 802.11n (" $n$ " signifying theoretical speeds up to 300 megabits per second). Bandwidth, the maximum data transfer rate, is also impacted by network switches and other hardware/wiring. Generally, student Internet consumption in 2013 called for gigabit Ethernet switches, which better met student desire to simultaneously connect two wireless devices, typically a laptop/tablet and a smartphone, when utilizing college union facilities. In the case of Georgia Tech, wireless network coverage was accomplished with 41 access points (increased from 17) over a 150,000 square foot facility. Access points were installed with greater density in locations with higher density seating or the potential for large audiences.

A significant role in many of the college unions in the United States is the management of conferences and events. Technology tools have enhanced this function, allowing for greater efficiencies by professionals in college unions in the planning and delivery of standard meetings as well as complex events. The age of reserving rooms in a hardbound ledger is long gone, with most scheduling managed through software and online access for clients, such as Event Management System (EMS), Resource 25, and Ungerboeck Software. These programs are set up to specifically house the details (e.g., square footage and furniture options) associated with each room within a college union. Details ranging from room setup, catering menu selection, and audio visual (AV) needs can be easily requested, confirmed, and changed by professionals. Such software also allows for better customer service and efficiency. Computer room diagramming, for example, helps the client to visualize their event, reduces the possibility of setup mistakes, and confirms in advance whether a desired furniture arrangement will adequately fit in a room.

\section{The Future Role of the Campus Bookstore and Retail Venues}

Over the years there have been various retail services in college unions, some that have thrived and others that have disappeared. College unions often house a variety of retail services that are available to the campus community and are frequently driven by community need and current retail trends within society. For example, the U.S. Education Secretary Arne Duncan stated that printed textbooks would be obsolete in the near 
future due to e-books and digital readers (von Glahn, 2013). This emergence of digital technology has greatly challenged the textbook industry (McDermott, North, Meszaros, Caywood, \& Danzell, 2011), bringing into question the role of the conventional campus bookstore, often found in college unions.

The University of Michigan assessed the future of the campus bookstore through interviews with public K-12 school administrators, higher education focus groups, and the analysis of media reports and industry trends. This revealed that serious technology enhancements have and will continue to alter the traditional college bookstore, with its future in question. The younger (grade school) generation is adapting well to new technology, suggesting a stronger affinity to resources, such as electronic readers, than current college students. While hard copy textbooks are still common for today's college students (McDermott et al., 2011), affordability will be a factor in the consideration for campuses transitioning to alternative electronic resources. Online textbook rentals, for example, provide students a less expensive option to obtain electronic course material on a short-term basis, and open source textbooks, which can be altered by faculty for their specific classes, provide a free resource for students to use online. There is no doubt that changes in the delivery of educational content will affect the purpose of the campus bookstore.

Conducting retail business over the Internet, or e-commerce, is a common service offering on college campuses. For example, campus bookstores typically offer their inventory of institutional logo clothing, gifts, supplies, and course materials online expanding the potential sales reach to include alumni. Links between online course registration systems and e-commerce textbook sites introduce a valued element of convenience for students buying required course materials. For example, Indiana University offers faculty the option of requiring e-textbooks that are then automatically added to the students bursar account when the student registers for the course. The campus community can also benefit from special access to ecommerce sites via authentication tools using university credentials, which allows customers to take advantage of negotiated discounts and special offers.

Technology tools can aid campus dining operations housed in a college union that struggle with overcrowding at peak intervals due to an influx of customers seeking food or coffee between classes and at primary meal periods. Mobile solutions have been introduced in the university environment to support remote ordering and payment to reduce wait times and increase sales. Additionally, unattended cash register systems have proven effective to increase customer throughput without increasing labor costs. For example, a Georgia Tech fast casual restaurant increased throughput of customers by nearly $10 \%$, saved $33 \%$ in cashier labor costs, and increased the average purchase by $7 \%$. 


\section{Student Organization Advising}

Student involvement is a critical component to student success (Astin, 1999). The role of technology within the physical structure of a college union often shadows the role technology plays in creating the conditions necessary to engage students in the campus programming college unions offer. Professionals working directly with student organizations are often stretched for time, expending efforts on transactional interactions that revolve around the logistics of recognizing a student organization on campus. This detracts from a more significant advising role, noted as encouraging student learning and development (Love \& Maxam, 2011). Technological tools, however, can enhance an advisor's ability to engage students more effectively and support student organizations, and create more time for relationship building.

A recent technological solution on college campuses is the use of cocurricular or student organization content management systems. Such resources provide "back of the house" data management for the student activities/organization office and seamless online access and resources for students. Content management systems, such as Collegiate Link, Symplicity, and Org Sync, typically offer the following types of resources:

Registration. An online process that captures organizational data.

Email. The ability for distribution options to push communication out to student organization officers, members, and subgroups.

Cocurricular transcript. Students can document their involvement and out of classroom experience.

Web pages. Student organizations can set up a web page through the management system and/or linking to their existing organizational web page.

Finances. Student organization finances can be managed with the institution's financial system, including online funding requests and account balances.

Student involvement. Event and involvement opportunities can be promoted to students.

Event assessment. Attendance can be tracked and online surveys created.

Rosters. Advisors or student organization leaders can manage membership lists, send out emails, and categorize involvement.

Also, a college union may operate movie programs, theaters, and performing arts venues that benefit from in-house box office capabilities and a software solution to sell and print tickets. Such systems typically support season ticketing, group discounts, customer accounts, communications, fundraising, and audit trail accounting for handling funds and ticket stock. Campus card systems provide tools to automate event access through electronic ticketing or verification of fee payment. Utilizing an online 
marketplace, such as Touchnet ${ }^{\circledR}$ and Sequoia Retail Systems ePOS, card systems can automate ticket purchases and store transactions that can be verified electronically utilizing handheld or installed access readers. This technology reduces the cost of ticket printing and handling, and eliminates the risk of inventory shrinkage. It also allows students to use their campus ID as verification of an e-ticket for admission to a specific event. These technology tools, which are frequently linked to the response of the millennial generations desire for immediate gratification, provide the opportunity for engaging students differently on campus (Lowery, 2004) and provide data to evaluate programs and services offered by a college union.

\section{Marketing}

Marketing the services and opportunities in a college union has moved far beyond advertising in the campus newspaper, to avenues such as digital displays, an effective web presence, and social media. Digital displays are becoming more common for effectively communicating to building patrons. Using connected system software allows information from multiple resources to be automatically pulled and displayed on building screens. For example, college union managers can display building events from EMS, highlight services, and broadcast emergency alerts from the campus police department. Digital displays can be a very effective visual tool, whether advertising retail services offered in the college union, displaying food vendor specials, or providing means to navigate the college union building. These digital displays can also be interactive, providing an opportunity for students to engage the display to specifically locate information that is pertinent to them. When connected to the broader campus information technology infrastructure digital displays in the college union can also be accessed by campus safety personnel to extend notification of important information in the event of an emergency.

Websites serve as the online brand identity of an organization and should reflect the same visual imagery and quality standards evident in the physical space of an organization. While a well-designed website is an important marketing tool, customers will need motivation and ease of access to navigate the site. Navigational links to social media, including image and video sharing, are common and can enhance attraction to the site. Online visitors expect to experience information, images, and services in a logical format for their daily lives and not to be forced into following virtual breadcrumbs based on organizational structures that are only meaningful to insiders. The main website page should display the organization's name, address, phone number, and basic operational information. Professionals in college unions will want to work directly with their informational technology services offices to ensure that branding and the internal structure of the website meet institutional guidelines. Professionals should also be 
aware that data from web analytics can be used to assess the effectiveness of communication, social media usage, and services offered.

When marketing a college union, it is important to understand that traditional college-age students fall into the "millennial" generational category, individuals born after 1982, considered to be coming of age in the new millennium (Strauss \& Howe, 2006). According to a Pew Research Center (2010) report on "millennial students," technology clearly plays an important role in their lives, and differently than other generations. "It's not just their gadgets-it's the way they've fused their social lives into them" (p. 13). In a number of areas, but especially social networking, millennial students far outpace older generations in their use of social networking sites such as Facebook.

There is little question that students operate in a world where Facebook, Twitter, and YouTube are an important part of how they carry out their everyday activities. In fact, $95 \%$ of entering freshmen reported spending time on social network sites (Pryor, DeAngelo, Palucki Blake, Hurtado, $\&$ Tran, 2011). College union professionals must look for ways to intentionally engage students through social media because operating in sync with students provides an access point for student involvement. For example, effectively using social media provides opportunities for students to connect not just with each other but also with the campus activities office to learn how to become involved on campus. Being familiar with and intentional in using social media provides different avenues for an advisor to engage with students, to learn of their interests, and to best support student organization endeavors. College union staff must reimagine their traditional functions in a new light. For example, the traditional role of the college union information desk is to disseminate information. Effectively using social media allows for two-way, rather than one-way, communication. For example, the information desk attendants could monitor social media on campus, pushing out content based on trends and what is being discussed, rather than waiting to be asked a one-on-one question at the physical desk.

Interestingly, even though students are heavily engaged in online social networks, this has not limited their involvement on campus, and in fact the opposite may be true. According to Heiberger and Harper (2008), 94\% of students reported using social networks weekly and spent no less time studying or participating in cocurricular activities than students who do not use social networks. The authors also indicated that students who more frequently use social networks also spend more time in campus activities such as student organizations. Similarly, a Higher Education Research Institute (2007) brief noted a positive correlation between social networking website use and college student engagement, with heavy users indicating more frequent daily interaction with close friends and strong connections to them. 


\section{Planning for the Future}

Intel cofounder Gordon Moore is associated with the concept that the processing power for computers will double every two years. Moore's law (Intel Corporation, 2005), as the concept has been termed, alludes to the speed at which technology changes, and the challenge of staying current. Recognizing this dilemma, here are some practical applications for professionals working in college unions to consider in planning for the "near" future.

Cloud computing describes the Internet as a "cloud" providing services that can replace the functionality of personal computers in terms of storage, software, and even platform functionality. Remote server storage offers broadly scalable, hosted solutions for web services, file storage, or software sharing and can fulfill the need for off-site data backup. The cost of cloud storage is offset by eliminating the need for staff to maintain onsite services and by eliminating cyclical hardware replacement costs. Software as a Service (SaaS) describes a cloud computing scenario that delivers software solutions via a compatible browser rather than installed on individual devices. A common example of SaaS is Google Docs, which provides software compatible with the Microsoft Office suite and file storage for shared documents. Broad adoption of cloud computing is considered inevitable in business as a cost-saving measure, viewed as outsourcing of technology assets (Monaco, 2012). Local storage of critical files is recommended to avoid loss of business continuity due to network failure or inaccessibility.

Tablet computers offer a mobile platform with sufficient digital real estate to effectively view large and complex data formats. Facility operations staff in the college union at Florida State University (Watson \& Wuest, 2012) adopted tablet computers and document sharing to view setup worksheets, share photographs for maintenance work orders, and to complete shift reports. This initiative resulted in cost savings, more accurate setup information, and more effective communications. One limitation observed was the difficulty of handling the tablet computer while also fulfilling the manual workload required for room setup.

A smartphone is defined as "a mobile phone offering advanced capabilities, often with PC-like functionality or able to download apps" (Google/IPSOS OTX MediaCT, 2011, p. 3). The proliferation of these devices on campus opens a new world of opportunity and challenge. Strategies specific to smartphone platforms, the user audience, and content format are necessary to capitalize on the opportunity to interact with students regardless of location. A Google/IPSOS OTX MediaCT (2011) study identified that $89 \%$ of online adults age 18-64 used their smartphone throughout the day. Most (89\%) used their devices for e-mail and social media, $82 \%$ indicated that they experienced a mobile advertisement, and nearly half were called to action because of the ad (visit website, visit store, and make purchase). While potentially enticing to college union marketing professionals, thorough planning is required before assuming the cost and complexity of 
addressing the mobile student through websites designed for smaller screens and finger navigation, or through a customized smartphone app.

Professionals in college unions must acknowledge the limited useful life of technology assets and plan for the financial impact of their replacement. The generally accepted life cycle for computers is 3-4 years, for displays and projectors 5-7 years, and for audio systems 10-15 years. Straightline depreciation is sufficient for most technologies as costs tend to decrease over time, especially for computer hardware. Annual maintenance for technology assets should be budgeted at $5-8 \%$ of the equipment value.

The cost of professional IT staff continues to rise at a faster pace than most other higher education specialties. First quarter 2013 indices show that IT staff pay is up $5.1 \%$ over prior year while administrative and clerical staff pay was half that increase $(2.6 \%)$ over the same period (PayScale, 2013). The level of expertise and the breadth of services that require IT staff involvement is also growing at a fast pace. Departments may require more in-house staff to manage complex web services, e-commerce sites, social media coordination, and AV technology. IT leadership staff play an increasingly dominant role in establishing and managing the strategic direction of organizations. This growth of IT expenses must be considered in planning the budget of a college union.

\section{Conclusion}

While it is important for professionals in college unions to understand student technology use and incorporate related applications into programs and services, such an effort is recognized as fairly complex (Junco \& Cole-Avent, 2008). Proficiency in the core competency area of technology is important, just as is putting a comprehensive and effective technology strategy in place. By embracing technology, college union professionals can expand student involvement opportunities and operate more efficient facilities while reducing costs. There is no denying the challenges involved with "staying current," as technology advances at a very fast pace. However, professionals in college unions must continue to develop in the technology arena to engage students through contemporary means and to respond to evolving campus needs.

\section{References}

American College Personnel Association \& National Association of Student Personnel Administrators (ACPA/NASPA). (2010). ACPA/NASPA professional competency areas for student affairs practitioners. Washington, DC: Author.

Association of College Unions International (ACUI). (2012). Core competencies for the college union and student activities profession. Retrieved from http://www.acui .org/content.aspx? menu_id=30\&id=9463

Astin, A. W. (1999). Student involvement: A developmental theory for higher education. Journal of College Student Development, 40(5), 518-529. 
Blimling, G. S. (2000). New technologies: Changing how we work with students. About Campus, 5(4), 3-7.

Butts, P., Beltramini, E., Bourassa, M., Connelly, P., Meyer, R., Mitchell, S., ... Willis, T. J. (Eds.). (2012). The college union idea (2nd ed.). Bloomington, IN: Association of College Unions International.

Chekwa, C., Thomas, E., Jr., \& Jones, V. J. (2013). What are college students' perceptions about campus safety? Contemporary Issues in Education Research, 6(3), 325332.

Duderstadt, J. J., Atkins, D. E., \& Van Houweling, D. (2006). Higher education in the digital age: Technology issues and strategies for American colleges and universities. Westport, CT: American Council on Education and Praeger Publishers.

Google/IPSOS OTX MediaCT. (2011). The mobile movement. Retrieved from http: //ssl.gstatic.com/think/docs/the-mobile-movement_research-studies.pdf

Heiberger, G., \& Harper, R. (2008). Have you Facebooked Astin lately? Using technology to increase student involvement. In R. Junco \& D. M. Timm (Eds.), New Directions for Student Services: No. 124. Using emerging technologies to enhance student engagement (pp. 19-35). San Francisco, CA: Jossey-Bass.

Higher Education Research Institute. (2007). College freshmen and online social networking sites. Retrieved from http://www.gseis.ucla.edu/heri/PDFs/pubs/briefs/brief -091107-SocialNetworking.pdf

$\mathrm{Hu}, \mathrm{S} .$, \& Kuh, G. D. (2001). Computing experience and good practices in undergraduate education: Does the degree of campus "Wiredness" matter? Education Policy Analysis Archives, 9(49). Retrieved from http://epaa.asu.edu/epaa/v9n49 .html

Intel Corporation. (2005). Excerpts from a conversation with Gordon Moore: Moore's law. Retrieved from http://large.stanford.edu/courses/2012/ph250/lee1/docs/Excepts _A_Conversation_with_Gordon_Moore.pdf

Jones, S. (2002). The Internet goes to college: How students are living in the future with today's technology. Washington, DC: Pew Internet and American Life Project.

Junco, R., \& Cole-Avent, G. A. (2008). An introduction to technologies commonly used by college students. In R. Junco \& D. M. Timm (Eds.), New Directions for Student Services: No. 124. Using emerging technologies to enhance student engagement (pp. 317). San Francisco, CA: Jossey-Bass.

Junco, R., \& Mastrodicasa, J. (2007). Connecting to the net generation: What higher education professionals need to know about today's students. Washington, DC: National Association of Student Personnel Administrators.

Lange, E. A., \& Kerr, S. G. (2013). Accounting and incentives for sustainability in higher education: An interdisciplinary analysis of a needed revolution. Social Responsibility Journal, 9(2), 210-219.

Love, P., \& Maxam, S. (2011). Advising and consultation. In J. H. Schuh, S. R. Jones, S. R. Harper, \& Associates (Eds.), Student services: A handbook for the profession (5th ed., pp. 413-432). San Francisco, CA: Jossey-Bass.

Lowery, J. W. (Ed.). (2004). New Directions for Student Services: No. 106. Student affairs for a new generation. San Francisco, CA: Jossey-Bass.

Martinez Aleman, A. M., \& Wartman, K. L. (2009). Online social networking on campus: Understanding what matters in student culture. New York, NY: Routledge.

Martinez Aleman, A. M., \& Wartman, K. L. (2011). Assessment and evaluation. In J. H. Schuh, S. R. Jones, S. R. Harper, \& Associates (Eds.), Student services: A handbook for the profession (5th ed., pp. 515-533). San Francisco, CA: Jossey-Bass.

McDermott, J., North, P., Meszaros, G., Caywood, J. A., \& Danzell, L. (2011). Exploring the path of bookstore trends. NACAS College Services, 11(4), 16-23.

McElvain, K., \& Smyth, C. (2006). Facebook: Implications for student affairs professionals. The Bulletin, 74(2), 18-22. 
Monaco, A. (2012). A view inside the cloud. Retrieved from http://theinstitute .ieee.org/technology-focus/technology-topic/a-view-inside-the-cloud

Nelson Laird, T. F., \& Kuh, G. D. (2005). Student experiences with information technology and their relationship to other aspects of student engagement. Research in Higher Education, 46(2), 211-233.

PayScale. (2013). Pay trends for information technology jobs. Retrieved from http://www.payscale.com/payscale-index-Q1-2013/job-categories/information -technology-jobs

Pew Research Center. (2010). Millennials: Confident. Connected. Open to change. Washington DC: Author.

Pryor, J. H., DeAngelo, L., Palucki Blake, L., Hurtado, S., \& Tran, S. (2011). The American freshman: National norms fall 2011. Los Angeles, CA: Higher Education Research Institute, UCLA.

Strauss, W., \& Howe, N. (2006). Millennials and the pop culture: Strategies for a new generation of consumers in music, movies, television, the Internet, and video games. Great Falls, VA: LifeCourse Associates.

Student Monitor. (2013). Retrieved from http://www.studentmonitor.com

von Glahn, M. (2013). Plug in: How to market and sell digital course materials. The College Store, 80(1), 22-30.

Watson, M., \& Wuest, M. (2012, November). Integrating iPads into union operations. Paper presented at the Region 6 Conference of the Association of College Unions International, Tallahassee, FL.

JOHN TAYLOR is the senior director of Auxiliary Services and director of University Unions at the University of Michigan.

RICH STEELE is the senior director of Auxiliary Services at Georgia Institute of Technology. 